Available online: http://openjournal.wdh.ac.id/index.php/edudharma

Edu Dharma Journal: Jurnal

Penelitian dan Pengabdian Masyarakat

ISSN (Print) 2597-890 X ，ISSN (Online) 2686-6366

\title{
GAMBARAN TINGKAT KEPATUHAN MASYARAKAT DALAM PENERAPAN PROTOKOL KESEHATAN POST VAKSINASI COVID-19
}

\author{
${ }^{1 *}$ Agus Mulyawan, ${ }^{2}$ Rita Sekarsari, ${ }^{3}$ Nuraini, ${ }^{4}$ Eriyono Budi \\ Fakultas Ilmu Kesehatan Universitas Muhammadiyah Tangerang, Jl. Taman Makam Pahlawan (TMP) Taruna No.2 Pengayoman, \\ Sukasari, Kota Tangerang, Banten 15118
}

\begin{tabular}{|c|c|}
\hline ARTICLE INFORMATION & $A B S T R A C T$ \\
\hline $\begin{array}{l}\text { *Corresponding Author } \\
\text { Rita Sekarsari, } \\
\text { E-mail: agusmulyawan530@gmail.com }\end{array}$ & $\begin{array}{l}\text { Covid-19 is still a serious world problem with the number of cases still } \\
\text { rising and falling every day. In response to this, the government is } \\
\text { currently aggressively humiliating the Covid-19 Vaccination program } \\
\text { and at the same time encouraging the public to continue to carry out } \\
\text { health protocols such as wearing masks, washing hands and maintaining }\end{array}$ \\
\hline $\begin{array}{l}\text { Keywords: } \\
\text { Keyword_1. Compliance } \\
\text { Keyword_2. Health protokol } \\
\text { Keyword_3. Covid-19 } \\
\text { Keyword_4. Vaccination }\end{array}$ & $\begin{array}{l}\text { in the application of post-Covid-19 vaccination health protocols in the } \\
\text { Pakuhaji Health Center Work Area. The design in this study was cross } \\
\text { sectional. Data collection using online and manual questionnaires. The } \\
\text { sample is } 85 \text { respondents who have been vaccinated against Covid-19 to } \\
1 \text { or } 2 \text {, respondents were taken by purposive sampling technique. The } \\
\text { results obtained as many as } 17 \text { respondents }(20 \%) \text { in the non-compliant } \\
\text { category and } 68 \text { respondents }(80 \%) \text { in the obedient category. And based } \\
\text { on the characteristics of the respondents age, gender, and education. } \\
\text { Based on this study, it was found that respondents with early adulthood } \\
\text { (18-40 years) were more obedient to the implementation of health } \\
\text { protocols. based on gender, female respondents were much more } \\
\text { obedient in implementing health protocols and furthermore based on } \\
\text { education level, respondents with middle to high education levels were } \\
\text { much more obedient in implementing health protocols. }\end{array}$ \\
\hline $\begin{array}{l}\text { Kata Kunci: } \\
\text { Kata Kunci_1. Kepatuhan } \\
\text { Kata Kunci_2. Protokol Kesahatan } \\
\text { Kata Kunci_3. Covid-19 } \\
\text { Kata Kunci_4. Vaksinasi }\end{array}$ & $\begin{array}{l}\text { A B S T R A K } \\
\text { Covid-19 hingga saat ini masih menjadi permasalahan dunia yang serius } \\
\text { dengan jumlah kasus yang masih naik turun setiap harinya. Dalam } \\
\text { menanggapi hal tersebut pemerintah saat ini sedang gencar malukan } \\
\text { program Vaksinasi Covid-19 dan sekaligus menganjurkan masyarakat } \\
\text { untuk tetap melakukan protokol kesehatan seperti memakai masker, } \\
\text { mencuci tangan dan manjaga jarak. Penelitian ini bertujuan untuk } \\
\text { mengetahui gambaran tingkat kepatuhan masyarakat dalam penerapan } \\
\text { protokol kesehatan post Vaksinasi Covid-19 di Wilayah Kerja } \\
\text { Puskesmas Pakuhaji. Desain pada penelitian ini adalah cross sectional. } \\
\text { Pengumpulan data menggunakan kuesioner secara online dan manual. } \\
\text { Sample berjumlah } 85 \text { responden yang sudah vaksinasi Covid-19 ke } 1 \\
\text { atau 2, responden diambil dengan teknik purposive sampling. Hasil } \\
\text { penelitian didapatkan sebanyak } 17 \text { responden (20\%) dengan kategori } \\
\text { tidak patuh dan } 68 \text { responden (80\%) dengan kategori patuh. Dan } \\
\text { berdasarkan karakteristik responden usia, jenis kelamin, serta } \\
\text { pendidikan. Berdasarkan penelitian ini, ditemukan responden dengan }\end{array}$ \\
\hline
\end{tabular}




\begin{tabular}{|l|l|l|}
\hline & $\begin{array}{l}\text { usia dewasa awal (18-40 tahun) lebih patuh terhadap penerapan protokol } \\
\text { kesehatan. Selain itu berdasarkan jenis kelamin, responden perempuan } \\
\text { jauh lebih patuh dalam penerapan protokol kesehatan dan selanjutnya } \\
\text { berdasarkan tingkat pendidikan, responden dengan tingkat pendidikan } \\
\text { menenga hingga tinggi jauh lebih patuh dalam penerapan protokol } \\
\text { kesehatan. }\end{array}$ \\
\hline & This is an open access article under the CC-BY-NC-SA license. \\
\hline EY NC SA
\end{tabular}




\section{PENDAHULUAN}

Covid-19 hingga saat ini masi menjadi permasalahan dunia yang serius dengan jumlah kasus yang masih naik turun setiap harinya. Menyerang orang tanpa tanpa memandang usia maupun jenis kelamin dan sudah dikategorikan sebagai pandemi global (WHO, 2020). Menurut data WHO (2021) pada tanggal 26 april 2021 sudah sebanyak 223 negara terjangkit kasus Covid-19, dengan total kasus secara global yaitu 148.3 juta kasus terkonfirmasi positif Covid-19, dengan kesembuhan 125.8 juta dan kasus meninggal dunia sebanyak 3.1 juta. Di Indonesia perkembangan kasus tercatat total kasus terkonfirmasi positif mencapai 1.6 juta, kesembuhan 1.5 juta dan kasus meninggal yaitu sebanyak 44.771 ribu (Kementrian Kesehatan RI, 2021).

Dalam menanggapi hal tersebut pemerintah telah mengeluarkan kebijakan atau peraturan untuk mencegah pertambahan jumlah kasus yaitu berupa protokol kesehatan penanganan Covid-19 (Kementerian Luar Negri, 2020). Menurut Peraturan Kementrian Kesehatan RI Nomor 9 Tahun (2020) tentang Pedoman Pembatasan Sosial Berskala Besar Dalam Rangka Percepatan Penanganan Covid19, PSBB didefinisikan sebagai pembatasan kegiatan tertentu penduduk dalam suatu wilayah yang kemungkinan terinfeksi Covid-19 untuk mencegah penyebaran Covid-19.

Selain itu pemerintah saat ini sedang melaksanakan program lainnya untuk memutus rantai penyebaran Covid19 yaitu dengan program vaksinasi Covid-19. Menurut Kementrian Kesehatan RI, (2021) vaksinasi Covid-19 diharapkan dapat mengurangi transmisi atau penularan Covid-19, menurunkan angka kesakitan dan kamatian akibat Covid-19. Mencapai kekebalan kelompok di masyarakat (hard imunity) dan melindungi masyarakat dari Covid-19 agar tetap produktif secara sosial dan ekonomi. Dengan dilakukannya vaksinasi Covid-19 maka terbentuk kekebalan kelompok dengan cakupan vaksinasi Covid-19 yang tinggi, minimal $60 \%$. Penularan tidak terjadi karena sebagian besar masyarakat memiliki kekebalan tubuh yang baik. Berdasarkan data program vaksinasi Covid-19 secara nasional, Pemerintah telah menargetkan sasaran vaksinasi sebanyak 181,5 juta vaksin Covid-19. Berdasarkan data yang didapat pada tanggal 26 april 2021 sampai dengan pukul 12.00. sudah sebanyak 10.8 juta masyarakat yang telah divaksinasin Covid-19 ke 1 dan 5,9 Juta masyarakat yang telah divaksinasi Covid-19 ke 2 (Kemenkes, 2021).

Dari hasil uraian data vaksinasi Covid-19 diatas, bahwasanya hasil 
tersebut belum mencapai target sasaran $60 \%$ untuk terbentuknya hard immunity. Sesuai yang disampaikan Anies, (2020) dimana hard immunity adalah konsep epidemologi yang menggambarkan bagiamana orang secara kolektif dapat mencegah infeksi jika 60\%-80\% penduduk telah mempunyai kekebalan. Kekebalan yang dimaksud adalah kekebalan yang dapat melalui program imunisasi atau infeksi secara alamiah. Selain itu dari hasil penelitian Abo \& Smith, (2020) untuk mengurangi krisis Covid-19 dengan vaksin akan memiliki efek positif yang signifikan pada risiko keseluruhan jika sebagian besar orang menerima vaksin atau jika vaksin tersebut digunakan untuk melengkapi tindakan perlindungan yang ada seperti memakai masker, mencuci tangan dan menjaga jarak.

\section{METODE}

Jenis penelitian yang digunakan adalah penelitian kuantitatif dengan menggunakan rancangan penelitian deskriptif analitik dengan desain cross sectional. Pada penelitian ini bertujuan mendeskripsikan karakteristik individu dengan tingkat kepatuhan penerapan protokol kesehatan post vaksinasi Covid19.
Penelitian ini dilakukan di Wilayah Kerja Puskesmas Pakuhaji pada bulan Mei - Juni 2021 dengan mengambil data menggunakan kuesioner secara online dan manual.

Populasi pada penelitian ini adalah masyarakat yang telah vaksinasi Covid-19 sesuai dengan kriteria sebanyak 107 orang yang telah vaksinasi Covid-19 tahap 1 atau 2 di Wilayah Kerja Puskesmas Pakuhaji Kabupaten Tangerang. Sampel penelitian ini menggunakan non probability sampling dengan teknik purposive sampling dengan sample sebanyak 85 responden.

HASIL (Times New Roman 12 point, Bold, spasi 1,5)

Pada penelitian ini diperoleh hasil dan pembahasan sebagai berikut :

Tabel 1. Distribusi Karakteristik Responden $(\mathrm{n}=85)$

\begin{tabular}{lcc}
\hline $\begin{array}{c}\text { Krakteristik } \\
\text { Responden }\end{array}$ & Jumlah & Persentasi \% \\
\hline Usia & & \\
\hline $18-40$ & 50 & 58,8 \\
\hline $41-60$ & 23 & 27,1 \\
\hline$>60$ & 12 & 14,1 \\
\hline Jenis Kelamin & & \\
\hline Laki-laki & 35 & 41,2 \\
\hline Perempuan & 50 & 58,8 \\
\hline Pendidikan & & \\
\hline Dasar & 18 & 21,2 \\
\hline Menengah & 42 & 49,4 \\
\hline Tinggi & 25 & 29,4 \\
\hline Total & 85 & $100 \%$ \\
\hline Sumber : Data primer & &
\end{tabular}


Berdasarkan keterangan tabel $1 .$. Menunjukan hasil karakteristik responden bahwa usia responden terbanyak adalah sekitar usia 18-40 tahun dengan jumlah responden sebanyak 50 responden dengan persentasi sebesar 58,8\%. Sedangkan jenis kelamin responden didominasi dengan jenis kelamin perempuan yaitu senbanyak 50 responden atau sebesar $58,8 \%$. Tingkat pendidikan terakhir menengah SMA/SMK/MA menjadi tingkat pendidikan responden terbanyak dengan jumlah 42 responden atau sebesar $49,4 \%$.

Tabel 2. Distribusi Tingkat Kepatuhan Penerapan Protokol Kesehatan Post Vaksinasi Covid-19 (n=85)

\begin{tabular}{lcc}
\hline \multicolumn{1}{c}{ Tingkat Kepatuhan } & Jumlah & Persentasi \% \\
\hline Memakai Masker & 9 & 10,6 \\
\hline Tidak Patuh & 76 & 89,4 \\
\hline Patuh & & 22,4 \\
\hline Mencuci Tangan & 19 & 77,6 \\
\hline Tidak Patuh & 66 & \\
\hline Patuh & & 43,5 \\
\hline Menjaga Jarak & 37 & 56,5 \\
\hline Tidak Patuh & 48 & $100 \%$ \\
\hline Patuh & 85 & \\
\hline Total & & \\
\hline
\end{tabular}

Berdasarkan keterangan table 2 menunjukan hasil tingkat kepatuhan masyarakat dalam penerapan protokol kesehatan memakai masker, mencuci tangan dan menjaga jarak post vaksinasi Covid-19. Berdasarkan tingkat kepatuhan memakai masker dari 85 responden, terdapat 76 responden $89,4 \%$ masyarakat patuh memakai masker. Selain itu dalam

\section{PEMBAHASAN}

Kepatuhan cukup erat dengan perilaku. Menurut WHO, (2011) menyebutkan bahwa patuh atau kepatuhan penerapan protokol kesehatan mencuci tangan, terdapat 66 responden atau sebesar 77,6\% masyarakat patuh dalam penerapan protokol kesehatan mencuci tangan. Dan untuk tingkat kepatuhan menjaga jarak fisik, terdapat 48 responden atau sebesar 56,5\% masyarakat patuh dalam penerapan protokol kesehatan menjaga jarak dengan orang lain.

merupakan kecendrungan untuk melakukan intruksi medikasi yang dianjurkan. Artinya masyarakat yang patuh ialah mereka yang memiliki sikap 
yang tunduk pada aturan-aturan dalam kelompok sosial masyarakat dalam bentuk lisan maupun tulisan agar setiap individu menjalankan perannya secara terstruktur dan seluruh kegiatannya berjalan dengan baik serta meninggalkan apa yang menjadi larangannya agar terhindar dari sanksi hukuman ataupun masalah kesehatan. Dalam penelitian ini menggambarkan tingkat kepatuhan masyarakat dalam penerapan protokol kesehatan post vaksinasi Covid-19 sehingga mampu mengukur tingkat kepatuhan masyarakat, sejauh mana untuk mengikuti intuksi yang telah dibuat terhadap kepatuhan menjalankan protokol kesehatan setelah vaksinasi Covid-19.

Pada penelitian mencakup karakteristik masyarakat dan tingkat kepatuhan masyarakat dalam penerapan protokol kesehatan post vaksinasi Covid19. Hasil penelitian ini menunjukkan bahwa sebagian masyarakat yang menjadi responden berusia 18-40 tahun (58,8\%), Sedangkan jenis kelamin responden didominasi dengan jenis kelamin perempuan $58,8 \%$.

Tingkat pendidikan terakhir menengah SMA/SMK/MA menjadi tingkat pendidikan responden terbanyak dengan jumlah 42 responden atau sebesar 49,4\%. Tingkat pendidikan merupakan faktor yang dapat mempengaruhi pemahaman seseorang terhadap penyerapan suatu informasi.

Hasil penelitian ini menjukan bahwa tingkat kepatuhan masyarakat post vaksinasi Covid-19 sebagian besar masyarakat berada pada kategori patuh $80 \%$ dan sisanya pada tingkat tidak patuh sebesar $20 \%$.

Berdasarkan tingkat kepatuhan masayarakat dalam penerapan protokol kesehatan memakai masker post vaksinasi Covid-19. Hasil ini menunjukan sebagian besar masyarakat berada dalam kategori patuh $89,4 \%$ dan sisanya pada kategori tidak patuh $10,6 \%$.

Tingkat kepatuhan masyarakat dalam penerapan protokol kesehatan mancuci tangan post vaksinasi Covid-19. Hasil ini menunjukan peningkatan kepatuhan dalam mencuci tangan sebesar $77,6 \%$ masyarakat patuh untuk mencuci tangan dan kategori tidak patuh dalam mencuci tangan yaitu sebanyak $22,4 \%$.

Selanjutnya pada tingkat kepatuhan masyarakat dalam penerapan protokol kesehatan menjaga jarak post vaksinasi Covid-19. Hasil penelitian ini juga menunjukan adanya peningkatan kepatuhan masyarakat delam menjaga jarak fisik sebesar 56,5\% masayarakat patuh untuk menjaga jarak namun masih ada masyarakat yang tidak patuh dalam menjaga jarak yaitu sebesar $43,5 \%$ 


\section{KESIMPULAN}

Berdasarkan hasil penelitian dan pembahasan yang telah diuraikan dapat disimpulkan bahwa gambaran tingkat kepatuhan masyarakat dalam penerapan protokol kesehatan post vaksinasi Covid19 saat ini dalam kategori patuh. Masyarakat mampu menjalankan protokol kesehatan Covid-19 walupun sudah divaksinasi Covid-19.

$\begin{array}{rrr}\text { Saran } & \text { yang } & \text { dapat peneliti } \\ \text { sampaikan } & \text { adalah } & \text { meningkatkan }\end{array}$
pendidikan kesehatan terkait pengetahuan masyarakat pentingnya menjaga protokol kesehatan setelah vaksinasi Covid-19. Selain itu bagi institusi pendidikan keperawatan, untuk terus melakukan mengembangkan model keperawatan sehingga dapat diimplementasikan dalam upaya pencegahan dan pengendalian Covid-19. Bagi petugas untuk lebih mengetahui dan memahami peran perawat sebagai petugas vaksinasi Covid-19 agar terus melakukan sosialisasi dan pemberdayaan masyarakat menyadarkan masyarakat dalam upaya pencegahan Covid-19.

\section{DAFTAR PUSTAKA}

Abo, S. M. C., \& Smith, S. R. (2020). Is a COVID-19 vaccine likely to make things worse? Vaccines, 8(4), 1-13. https://doi.org/10.3390/vaccines8040 761
Afrianti, N., \& Rahmiati, C. (2021). Faktor-Faktor Yang Mempengaruhi Kepatuhan Masyarakat Terhadap Protokol Kesehatan Covid-19. Jurnal Ilmiah STIKES Kendal, 11(1), 113-124.

Anies. (2020). Covid-19: Seluk Beluk Corona Virus (N. Hidayat (Ed.); I). Arruzz Media.

Blass. (1999). The milgram paradigm after 35 years: Some things we now know about obedience to authority. Journal of Applied Social Psychology, 29(5), 955-978. https://doi.org/10.1111/j.1559-

1816.1999.tb00134.x

Dawson, et al. (2021). What Does a Multi-Dose Series Mean for the COVID-19 Vaccination Effort? Feb 05, 2021.

Devi Pramita Sari, \& Nabila Sholihah 'Atiqoh. (2020). Hubungan Antara Pengetahuan Masyarakat Dengan Kepatuhan Penggunaan Masker Sebagai Upaya Pencegahan Penyakit Covid-19 Di Ngronggah. Infokes: Jurnal Ilmiah Rekam Medis Dan Informatika Kesehatan, 10(1), 5255.

https://doi.org/10.47701/infokes.v10i 1.850

Dharma, et al. (2011). Metedologi Penelitian Keperawatan: Panduan Melaksanakan dan Menerapkan Hasil Penelitian (Revisi). Trans Info Media.

Dwirusman, et al. (2020). Peran Dan Efektivitas Masker Dalam Pencegahan Penularan Corona Virus Disease 2019 (Covid-19). Jurnal Medika Hutama, 2(1), 412-420.

Hacisuleyman, et al. (2021). Vaccine Breakthrough Infections with SARS- 
CoV-2 Variants. New England Journal of Medicine, 1-7. https://doi.org/10.1056/nejmoa21050 00

Hakam, A. (2020). 411 Orang di Semarang Kena COVID-19 Usai Divaksin.

https://siagacorona.semarangkota.go. id/

Hidayat. (2012). Riset Keperawatan dan Teknik Penulisan Ilmiah (Nurchasanah (Ed.); II). Salemba Medika.

http:/www.penerbitsalemba.com

Kementerian Kesehatan RI. (2020). Pertanyaan dan Jawaban Terkait Covid-19. Minggu, 01 Maret 2020. https://www.kemkes.go.id/article/vie w/20031600011/pertanyaan-danjawaban-terkait-covid-19.html

Kementerian Kesehatan RI. (2021a). Data Vaksinasi Covid-19. Kemenkes.go.id

Kementerian Kesehatan RI. (2021b). Question ( Faq ) Pelaksanaan Vaksinasi Covid-19. 2020, 1-16.

Peraturan menteri kesehatan republik indonesia nomor 9 tahun 2020 tentang pedoman pembatasan sosial berskala besar dalam rangka percepatan penanganan corona virus disease 2019 (covid-19), Kemenkes.go.id 9 (2020). https://doi.org/10.4324/97810030609 $18-2$

Kementrian Kesehatan RI. (2021). Vaksinasi Covid-19 Lindungi Diri, Lindungi Negeri. Kementerian Kesehatan RI, 9, 22-50.

Krisna. (2020). Menakar Kepatuhan Warga Selama PSBB. Kompas.Id. https://www.kompas.id/baca/riset/20 20/05/16/menakar-kepatuhan-warga- selama-psbb/

Pinasti. (2020). Analisis Dampak Pandemi Corona Virus Terhadap Tingkat Kesadaran Masyarakat dalam Penerapan Protokol Kesehatan. Wellness And Healthy Magazine, 2(2), 237-249. https://doi.org/10.30604/well.022.82 000107

Proverawati \& Andhini. (2017). Imunisasi dan Vaksin (II). Nuha Offset.

Putra. (2020). Judul : analisis determinan kepatuhan masyarakat kecamatan percut sei tuan, kabupaten deli: Ilham Mirzaya Putra. 2019. http://repository.uinsu.ac.id/10662/1/ Laporan Penelitian FINAL.pdf

Satuan Tugas Penanganan COVID-19. (2021). Monitoring Kepatuhan Protokol Kesehatan Tingkat Nasional. In 07 Februari. https://covid19.go.id/storage/app/me dia/Analisis Data COVID-19 Indonesia/2021/Februari/Monitoring Kepatuhan Protokol Kesehatan per 07 Februari 2021_vPublish.pdf

Schulman. (2021). Why Do You Need Two Doses for Some COVID-19 Vaccines? On March 5, 2021. https://www.healthline.com/health/w hy-two-doses-of-covid-vaccine

Simanjuntak, et al. (2020). Gambaran Kepatuhan Masyarakat Menerapkan Protokol Kesehatan COVID-19 Di Tempat Umum Periode September 2020 di DKI Jakarta. Fakultas Kedokteran Universitas Kristen Indonesia, September 2020.

Sugiyono. (2012). Metode Penelitian Kuantitatif, Kualitatif dan $R \& D$. ALFABETA, $\mathrm{CV}$. www.cvalfabeta.com 
Sugiyono. (2019). Metode Penelitian Kuantitatif, Kualitatif $d s n \quad R \& D$ (Sutopo (Ed.); 2nd ed.). ALFABETA, $\quad$ CV. www.cvalfabeta.com

Swaesti, E. (2020). Buku Pedoman Pencegahan dan Penanganan Corona Virus (Emirfan (Ed.); I). Javalitera.

Word Health Organization. (2020). Pertanyaan dan jawaban terkait Coronavirus.

https://www.who.int/indonesia/news/ novel-coronavirus/qa/qa-for-public

World Health Organization. (2011). National Institute For Health and Clinical Excellence: Centre for Clinical Practice Review consultation document. Review Literature And Arts of The Americas, June, 1-113.

World Health Organization. (2020). Anjuran mengenai penggunaan masker dalam konteks COVID-19. World Health Organization, April, $1-17$.

https://www.who.int/docs/defaultsource/searo/indonesia/covid19/anjur an-mengenai-penggunaan-maskerdalam-konteks-covid-19-june20.pdf? sfvrsn=d1327a85_2 